\title{
EVALUASI VALUE PROPOSITION PADA USAHA KECIL PARANI CAR WASH
}

\author{
Rinanda Bagus Anarta Pratama ${ }^{1}$, Liliani ${ }^{2}$ \\ Internasional Business Management, Universitas Ciputra \\ e-mail: ${ }^{1}$ rinandabap@gmail.com, ${ }^{2}$ liliani@ciputra.ac.id
}

\begin{abstract}
This study aimed to evaluate the Value Proposition in Parani Car Wash, a home-call car cleaning startup business. The Value Proposition is viewed as part of Osterwalder's Business Model Canvas and the SWOT approach is used to describe and explain the current Value Proposition of Parani Car Wash. This research uses qualitative approach with descriptive analysis. Data collection method in this study is using semi-structured interview technique. There are 9 informants interviewed, consisting of two customers of the company, two of the owners of similar companies, an expert, and four managers of the company. The results of SWOT approach indicates the strength of the Value Proposition is aligned with the needs of customers, while the weakness is related to network. Opportunities are available regarding expansion of operational areas and service variants, but there are threats related to competition.
\end{abstract}

Keywords: value proposition, business model canvas, SWOT, startup business

\section{PENDAHULUAN}

Model bisnis yang inovatif diperlukan perusahaan agar dapat menghadapi persaingan yang makin kompetitif. Model bisnis yang tepat sangat penting agar perusahaan dapat menciptakan nilai yang superior dan membangun kekuatan kompetitif. Giesen, Berman, Bell dan Blitz pada Setijawibawa (2015) mengatakan, "Anticipating massive change across diverse industries, top-performing CEOs are focusing on business model innovation as a path to competitive power and growth”. Tujuan dari inovasi model bisnis adalah menciptakan nilai bagi perusahaan, konsumen, dan masyarakat. Salah satu metode yang dapat digunakan untuk mendeskripsikan, menggambarkan, menilai, dan mengubah model bisnis adalah Business Model Canvas atau BMC (Osterwalder dan Pigneur, 2010).

Parani Car Wash adalah usaha startup yang didirikan pada tahun 2014, bergerak dalam bidang jasa yang menawarkan cuci mobil dengan inovasi sistem panggilan. Untuk dapat mening- katkan kekuatan kompetitif dan pertumbuhan perusahaan, Parani Car Wash telah merancang model bisnis dengan Business Model Canvas. Hal ini dikarenakan BMC dapat membantu perancangan konsep model bisnis yang sederhana dan relevan, di mana setiap perusahaan dapat menggambarkan dan memanipulasi model bisnis untuk membuat strategi baru, menguji prakonsepsi dan efisiensi serta pembuatan value yang efektif.

Salah satu elemen Business Model Canvas yang penting bagi perusahaan adalah value proposition atau nilai tambah. Sebelum mencari pelanggan, Parani Car Wash harus memiliki value proposition sebagai pembeda dari kompetitor dan sebagai daya tarik bagi pelanggan. value proposition merupakan keunikan atau keunggulan perusahaan yang sering menjadi alasan utama seseorang tertarik ingin membeli produk atau jasa (Osterwalder dan Pigneur, 2010). Gambar 1 menunjukkan value proposition utama Parani Car Wash, yaitu pelanggan tidak perlu keluar 


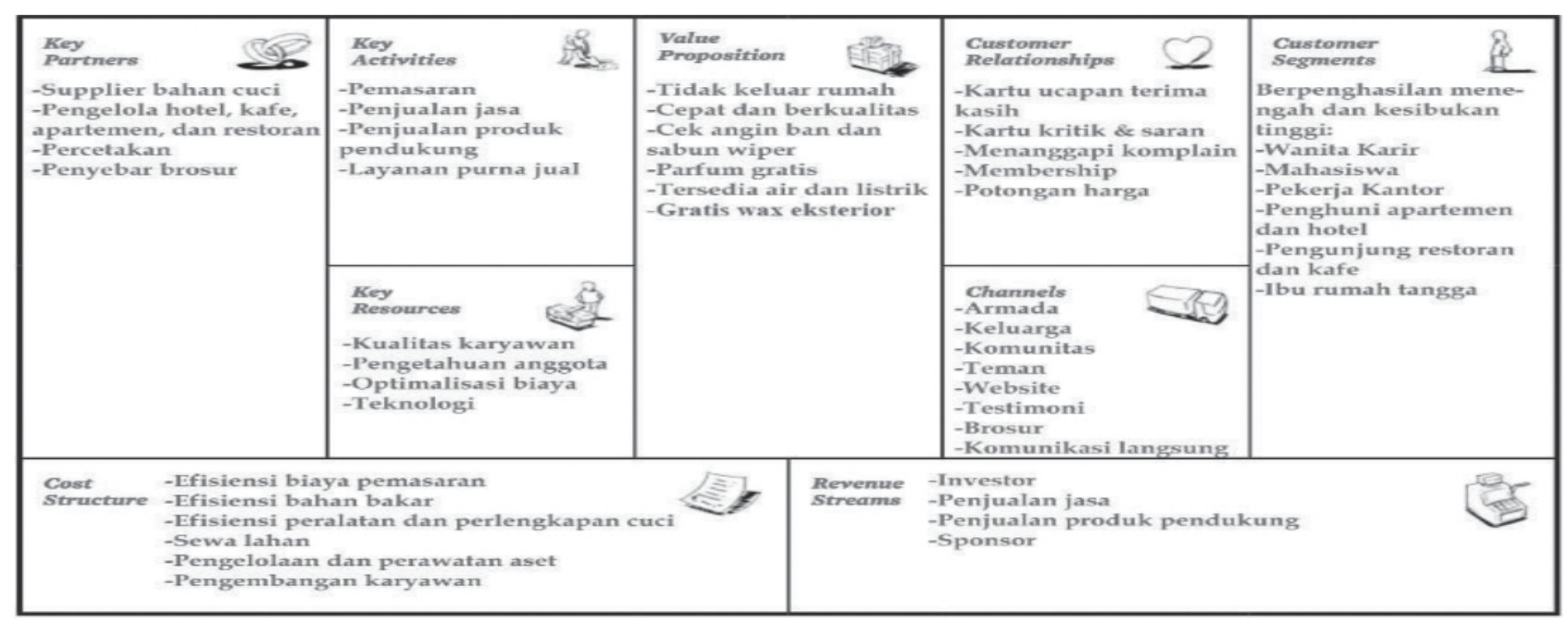

Gambar 1 Model Bisnis Parani Car Wash

Sumber: Data internal perusahaan

rumah, menyediakan air dan listrik, dan gratis wax eksterior mobil. Value proposition pendukung dari segi pelayanan adalah pengerjaan cepat, sabun berkualitas dengan $\mathrm{PH}$ seimbang yang tidak merusak lapisan cat, gratis cek dan isi angin ban dan sabun wiper, dan gratis parfum.

Parani Car Wash saat ini ingin terus meningkatkan kualitas pelayanan agar dapat bersaing dengan kompetitor. Pemenuhan value proposition ini harus ditunjang dengan elemen-elemen lain pada Business Model Canvas. Value proposition yang ditentukan oleh Parani Car Wash ditujukan kepada segmen pelanggan masyarakat Surabaya kelas menengah dengan kesibukan tinggi, di antaranya adalah wanita karier, mahasiswa, penghuni apartemen dan hotel, pengunjung restoran dan kafe, serta ibu rumah tangga. Parani Car Wash melakukan berbagai cara untuk mendapatkan loyalitas pelanggan dengan melakukan customer relationship di antaranya memberi kartu ucapan terima kasih, meminta kritik dan saran, menanggapi keluhan, membership, dan pemberian potongan harga pada hari tertentu. Channel yang digunakan Parani Car Wash adalah melalui armada sebagai kendaraan opera- sional dan media promosi, keluarga, komunitas, teman, website, testimoni, brosur, dan komunikasi secara langsung. Parani Car Wash memiliki kerjasama dengan pemasok bahan cuci, percetakan, penyebar brosur, serta pengelola hotel, apartemen, kafe, dan restoran sebagai key partner. Key resource berupa karyawan yang berkualitas, pengetahuan anggota dalam hal bisnis, optimalisasi biaya, dan teknologi membantu perusahaan dalam menjalankan bisnis. Key activities Parani Car Wash adalah pemasaran, penjualan jasa, penjualan produk pendukung, dan layanan purna jual. Sedangkan cost structure terdiri dari biaya pemasaran, bahan bakar, perlengkapan dan peralatan cuci, sewa lahan, pengelolaan dan pemeliharaan aset, dan pengembangan karyawan. Revenue structure Parani Car Wash terdiri dari penjualan jasa, penjualan produk pendukung, investor atau franchisee dan sponsor. Setiap elemen yang ada harus saling terhubung dan mendukung kesuksesan value proposition Parani Car Wash.

Osterwalder dan Pigneur (2010) mengemukakan sebelas elemen dalam pembuatan value proposition, yaitu newness, performance, cus- 
tomization, getting the job done, design, brand/ status, price, cost reduction, risk reduction, accessibility, dan convenience/usability. Namun Parani Car Wash belum mampu memenuhi value proposition yang ditetapkan secara konsisten. Hal ini ditunjukkan pada Tabel 1. Penelitian oleh Lund dan Nielsen (2014) menunjukkan bahwa bisnis start-up sering memiliki gambaran yang sangat buruk terhadap hubungan antara kegiatan yang dilakukan, sumber daya yang diperlukan, dan cara mengonfigurasi keterlibatan mitra dalam model bisnis mereka serta dalam penciptaan value proposition. Oleh karena itu, perlu dilakukan evaluasi lebih lanjut terhadap value proposition Parani Car Wash. Evaluasi akan dilakukan menggunakan pendekatan SWOT (strength, weakness, opportunity, threat) agar dapat mengidentifikasi berbagai faktor secara sistematis didasarkan pada logika yang dapat memaksimalkan kekuatan dan peluang, namun secara bersamaan dapat meminimalkan kelemahan dan ancaman (Rangkuti, 2015). Pendekatan SWOT pada value proposition memungkinkan penilaian dan evaluasi yang terfokus (Osterwalder dan Pigneur, 2010). Hasil evaluasi diharapkan mampu meningkatkan kekuatan kompetitif untuk pertumbuhan Parani Car Wash di masa yang akan datang.

Tabel 1.1 Value Proposition Parani Car Wash yang Tidak Konsisten

\begin{tabular}{|c|l|l|}
\hline No. & \multicolumn{1}{|c|}{ Inkonsistensi } & \multicolumn{1}{|c|}{ Elemen } \\
\hline 1. & $\begin{array}{l}\text { Parani belum kerjasama dengan perkantoran, hotel, kafe, } \\
\text { apartemen dan restoran sehingga apabila ada pelanggan } \\
\text { yang meminta cuci di tempat tersebut tidak dapat dipenuhi. }\end{array}$ & $\begin{array}{l}\text { Getting the Job } \\
\text { Done, Accessibility }\end{array}$ \\
\hline 2. & $\begin{array}{l}\text { Tidak semua wilayah dapat didatangi, hanya di Surabaya } \\
\text { Barat. }\end{array}$ & $\begin{array}{l}\text { Getting the Job Done, } \\
\text { Accessibility }\end{array}$ \\
\hline 3. & $\begin{array}{l}\text { Layanan wax gratis ditiadakan, karena membutuhkan biaya } \\
\text { yang tinggi, waktu pengerjaan lama, dan keterbatasan ke- } \\
\text { mampuan karyawan. }\end{array}$ & Price \\
\hline 4. & $\begin{array}{l}\text { Layanan cek angin dan pompa ban gratis ditiadakan karena } \\
\text { membutuhkan biaya yang tinggi dan menambah durasi. }\end{array}$ & Price \\
\hline 5. & $\begin{array}{l}\text { Ketika konsumen meminta cuci pada saat jadwal padat, } \\
\text { pelanggan harus mengantre dan ditawarkan ganti jam bahkan } \\
\text { sampai ganti hari. }\end{array}$ & Risk Reduction, Convenience \\
\hline 6. & $\begin{array}{l}\text { Tidak bisa menerima pesanan yang mendadak dan terburu- } \\
\text { buru. }\end{array}$ & Risk Reduction, Convenience \\
\hline 7. & $\begin{array}{l}\text { Tandon air hanya cukup untuk 3 mobil, ketika ada pesanan } \\
\text { cuci beruntun harus meminta waktu untuk mengisi air, bah- } \\
\text { kan pernah sampai menggunakan air dari rumah pelanggan } \\
\text { karena pelanggan ingin cuci mobil segera selesai. }\end{array}$ & Performance \\
\hline 8. & $\begin{array}{l}\text { Generator listrik hanya ada satu, ketika rusak saat mencu- } \\
\text { ci maka harus meminta listrik dari rumah pelanggan. }\end{array}$ & Performance, Convenience \\
\hline
\end{tabular}




\section{REFERENSI}

\section{Business Model Canvas}

Pembentukan dan pengembangan bisnis tidak hanya memerlukan strategi, tetapi juga inovasi berupa cara-cara baru untuk menciptakan nilai bagi pelanggan, pemasok, dan mitra. Hasil dari inovasi model bisnis sering memengaruhi keseluruhan perusahaan (CasadesusMasanell dan Zhu, 2013). Salah satu metode yang dapat digunakan untuk inovasi model bisnis adalah Business Model Canvas atau BMC (Osterwalder \& Pigneur, 2010). BMC dengan elemen atau parameter yang menentukan pertumbuhan yang berkelanjutan (Sabanti pada Dudin et al., 2015) dapat menjadi alat yang membantu merasionalkan bagaimana sebuah perusahaan membuat, menangkap, dan mengantarkan nilai (Osterwalder dan Pigneur, 2010). BMC memiliki sembilan elemen, yaitu customer segment, value proposition, channels, customer relationship, revenue stream, key resources, key activities, key partnership, dan cost structure (Osterwalder et al., 2014).

\section{Value Proposition}

Value proposition adalah alasan mengapa konsumen beralih dari satu perusahaan ke perusahaan lainnya dikarenakan dapat memecahkan persoalan atau memenuhi kebutuhan konsumen dengan menggunakan sekumpulan produk atau jasa yang mengikuti persyaratan dari segmen pelanggan (Osterwalder dan Pigneur, 2010). Menurut Kerin et al. (2013), value proposition dapat memberikan manfaat dan menciptakan nilai untuk pembeli yang ditargetkan. Elemenelemen yang mampu mendorong pembentukan value proposition dijelaskan pada Tabel 2 .

Value Proposition berdasarkan inovasi dapat memastikan keunggulan kompetitif yang berke- lanjutan, serta evaluasi value proposition dapat dilakukan dengan pendekatan Business Model Canvas (Bonazzi dan Zilber, 2014). Osterwalder dan Pigneur (2010) menggunakan analisis SWOT pada elemen value proposition untuk melakukan penilaian dan evaluasi yang terfokus pada aspekaspek berikut.

a. Strength atau kekuatan

1) Value proposition perusahaan selaras dengan kebutuhan pelanggan.

2) Value proposition perusahaan memiliki dampak jaringan bisnis yang luas.

3) Pelanggan perusahaan sangat puas.

b. Weakness atau kelemahan

1) Value proposition perusahaan dan kebutuhan pelanggan tidak sejalan

2) Value proposition perusahaan tidak memiliki dampak jaringan

3) Perusahaan sering menerima keluhan

c. Opportunity atau peluang

1) Perusahaan dapat menghasilkan pendapatan berulang.

2) Perusahaan dapat menentukan kebutuhan tambahan pelanggan.

3) Perusahaan dapat menentukan pelengkap atau perluasan nilai.

4) Perusahaan dapat melakukan pekerjaan lain untuk pelanggan.

d. Threat atau ancaman

1) Ketersediaan produk dan jasa substitusi.

2) Pesaing mengancam untuk menawarkan harga atau nilai yang lebih baik.

\section{METODOLOGI PENELITIAN}

Penelitian akan dilakukan dengan menggunakan pendekatan kualitatif di mana data secara diungkapkan secara deskriptif melalui kata-kata secara tertulis maupun lisan dari orang-orang yang diamati. Subjek penelitian ini adalah empat 
Tabel 2 Elemen-Elemen Value Proposition

\begin{tabular}{|c|c|c|}
\hline No. & Elemen & Penjelasan \\
\hline 1. & Newness & $\begin{array}{l}\text { Value proposition dibuat untuk menjawab kebutuhan baru kon- } \\
\text { sumen yang sebelumnya tidak dipertimbangkan karena belum } \\
\text { ada penawaran yang serupa. }\end{array}$ \\
\hline 2. & Performance & $\begin{array}{l}\text { Memperbaiki performa produk atau jasa telah secara tradi- } \\
\text { sional menjadi cara umum untuk membuat value. }\end{array}$ \\
\hline 3. & Customization & $\begin{array}{l}\text { Membuat produk atau jasa yang menjawab kebutuhan spesifik } \\
\text { konsumen individu atau consumer segment. }\end{array}$ \\
\hline 4. & Getting the job done & $\begin{array}{l}\text { Terkadang value terbuat karena ingin menolong konsumen } \\
\text { menyelesaikan sesuatu yang mereka perlukan. }\end{array}$ \\
\hline 5. & Design & $\begin{array}{l}\text { Desain adalah elemen yang penting tetapi susah untuk di- } \\
\text { ukur. Produk mencolok karena memiliki desain yang sangat } \\
\text { baik. }\end{array}$ \\
\hline 6. & Brand/status & $\begin{array}{l}\text { Terkadang konsumen mendapatkan value dalam hal kebanggaan } \\
\text { (prestige) ketika memakai produk merek tertentu. }\end{array}$ \\
\hline 7. & Price & $\begin{array}{l}\text { Harga dapat menjadi elemen yang penting ketika perusahaan } \\
\text { menargetkan konsumen yang sensitive terhadap harga dengan } \\
\text { menawarkan value yang sama pada harga yang lebih rendah. }\end{array}$ \\
\hline 8. & Cost reduction & $\begin{array}{l}\text { Membantu konsumen untuk mengurangi biaya adalah salah satu } \\
\text { cara penting dalam membuat value, karena konsumen merasa } \\
\text { menghemat. }\end{array}$ \\
\hline 9. & Risk reduction & $\begin{array}{l}\text { Penyediaan value yang meminimkan bahkan menghilangkan } \\
\text { kemungkinan risiko yang akan terjadi sangat membantu konsu- } \\
\text { men. }\end{array}$ \\
\hline 10. & Accessibility & $\begin{array}{l}\text { Menyediakan produk dan jasa untuk konsumen yang sebe- } \\
\text { lumnya tidak memiliki akses merupakan salah satu cara mem- } \\
\text { buat value. }\end{array}$ \\
\hline 11. & Convenience/ usability & $\begin{array}{l}\text { Membuat produk menjadi lebih nyaman atau lebih mudah digu- } \\
\text { nakan dapat membuat value walaupun hanya sedikit. }\end{array}$ \\
\hline
\end{tabular}

Sumber: Osterwalder dan Pigneur (2010)

orang manajemen usaha Parani Car Wash, seorang pemilik perusahaan cuci mobil panggilan sejenis, seorang pemilik usaha cuci konvensional yang telah berdiri lebih dari dua tahun, seorang pakar yang mendalami $B M C$ dan dua orang pelanggan yang pernah menggunakan jasa Parani Car Wash lebih dari lima kali. Manajemen internal perusahaan dipilih untuk mendapatkan sudut pandang tentang model bisnis perusahaan dan kondisi internal perusahaan. Pemilik usaha sejenis dipilih untuk mendapatkan gambaran dan pembanding value proposition usaha cuci mobil. Sedangkan pelanggan dipilih untuk memberikan gambaran mengenai value proposition Parani Car Wash sekaligus memperoleh gambaran kebutuhan pelanggan terhadap jasa cuci mobil panggilan secara lebih mendalam.

Pengumpulan data dilakukan dengan wawancara yang merupakan percakapan dengan maksud-maksud tertentu. Pada metode penelitian 
ini peneliti dan narasumber bertemu langsung untuk mendapatkan informasi secara lisan. Wawancara dilakukan secara semi-terstruktur untuk mencairkan suasana namun tetap pada garis utama penelitian dan menemukan permasalahan secara lebih terbuka, di mana pihak yang diajak wawancara diminta lebih dalam lagi untuk menyampaikan pendapat dan ide-idenya (Sugiyono, 2015).

Uji validitas dan reliabilitas sangatlah penting dalam sebuah penelitian. Validitas data, berupa ketepatan antara data yang terjadi pada objek penelitian dengan data yang dapat dilaporkan oleh peneliti diperoleh melalui member check. Peneliti menggunakan triangulasi sumber, yaitu mendapatkan data dari perusahaan sejenis, pakar, konsumen, dan anggota internal Parani Car Wash dengan teknik yang sama untuk melihat konsistensi maupun keberagaman pada suatu topik (Sugiyono, 2015). Analisis data dilakukan dengan menerapkan empat tahap kegiatan menurut Miles dan Huberman, yang terdiri dari reduksi data, penyajian data, perbandingan data, verifikasi dan penarikan kesimpulan (Sugiyono, 2015).

\section{HASIL PENELITIAN DAN PEMBAHASAN}

\section{Hasil Analisis Data}

Berdasarkan hasil wawancara yang telah dilakukan dengan sembilan narasumber, daya yang didapatkan memiliki kaitan langsung dengan penelitian yang dilakukan. Pengumpulan data dilakukan dengan cara bertemu langsung dan melakukan rekaman suara sebagai bukti wawancara. Wawancara terlebih dahulu dilakukan kepada pakar, perusahaan sejenis, dan pelanggan yang hasilnya diinformasikan kepada internal perusahaan untuk dijadikan bahan kajian, selanjutnya pihak internal perusahaan menyampaikan evaluasi dan pendapatnya. Analisis wawancara dengan menggunakan coding, cara membaca coding adalah lampiran-halamannama narasumber-baris. Contoh (F-2-FM-5) yang berarti kutipan diambil dari lampiran Fhalaman 1-Ferdyo Muhammad-baris 5.

Analisis SWOT pada elemen value proposition adalah analisis yang dilakukan untuk mengetahui faktor internal berupa kekuatan dan kelemahan, serta faktor eksternal berupa peluang dan ancaman pada value proposition yang didapat dari hasil wawancara. Kecocokan tersebut akan diklarifikasikan menjadi empat jenis yaitu strength, weakness, opportunity, dan threat.

\section{Analisis Strength dan Weakness}

1. Value Proposition Selaras dengan Kebutuhan Pelanggan

Hasil wawancara dengan pelanggan dan internal perusahaan menunjukkan bahwa value proposition Parani Car Wash selaras dengan kebutuhan pelanggan yaitu tidak perlu keluar rumah, tidak antre di ruang tunggu, serta menyediakan air dan listrik. Elemen value proposition yang sudah sesuai dengan kebutuhan pelanggan adalah performance, getting the job done dan convenience.

\footnotetext{
"Kalau saya prefer gini sih, anak saya nggak rewel, ayo ma cepetan pulang tempatnya kotor, gitu kan" (G-9-EN-3).

"ehm... waktu sih. Kalau misal pengen cuci mobil siang-siang panas kan males to keluar" (H-3SD-27).
}

Keselarasan value proposition terhadap kebutuhan pelanggan ini merupakan sebuah kekuatan bagi Parani Car Wash dan harus ditingkatkan, mengingat pelanggan bersifat dinamis. Heinonen et al (2013) menjelaskan bahwa value 
terbentuk dan tertanam dalam realitas dan kehidupan pelanggan yang bersifat sangat dinamis dan multi-kontekstual, sehingga perusahaan perlu melihat kebutuhan pelanggan lebih jauh. Hal ini selaras dengan pernyataan pakar yang menjelaskan bahwa konsumen merupakan elemen yang dinamis dan perusahaan perlu melihat kebutuhan pelanggan.

“... customer itu digambarkan kalau di value proposition design itu sebagai eee salah satu elemen yang bergerak dinamis, jadi dilihat mereka ini kerjanya apa, task yang berusaha diselesaikan customer itu apa, seperti itu..." (I-2-GA-2).

Pernyataan tersebut didukung oleh hasil wawancara dengan manajemen internal bahwa Parani Car Wash harus bisa mencari tahu kebutuhan pelanggan untuk bisa menentukan value proposition.

“...Value proposition kita ya dicocokkan dengan mereka mereka itu, bukan bukan dia yang mencocokkan kita. Dia membutuhkan apa dan kita semakin berkembang dan semakin ee pengen memenuhi kebutuhan mereka...” (L-3-AI-5).

Osterwalder, et al. (2014) juga menjelaskan bahwa dengan melihat kebutuhan pelanggan, value proposition dan model bisnis akan lebih efektif serta menguntungkan bagi perusahaan.

\section{Perusahaan belum Memiliki Dampak Jaringan yang Luas}

Menurut Messersmith dan Wales pada Zacca et al (2015), hubungan yang kuat dengan jaringan bisnis dapat membantu perusahaan dalam mengumpulkan informasi dan ide untuk pemecahan masalah, bersamaan dengan kemampuan belajar serta dukungan moral dan teknis. Berdasarkan hasil wawancara dengan pakar, cara menentukan dampak jaringan adalah dengan melihat channel, customer relationship, key resources, dan key activities.

\begin{abstract}
"Channel, nah, tergantung channel dengan customer relationship-nya. Itu untuk dampak jaringan. Sedangkan kalau untuk ke supplier ke belakang, sama ditentukan dari key resources yang dibutuhkan... Jadi begini, hubungannya key partners... key partners, key resources, key activities dengan value proposition apa, adalah hubungannya, value proposition ini hanya bisa dihasilkan dari key activities, yang sumber dayanya diambil dari key resources, yang didapatkan dari key partners, yang dibiayai oleh cost" (I-3-GA-15).
\end{abstract}

Parani Car Wash belum memiliki dampak jaringan yang luas karena tidak memiliki key partners, channels, dan key resources yang baik, dan belum ada key activities yang bertujuan untuk perbaikan dalam hal jaringan bisnis. Parani Car Wash yang belum memiliki badan usaha juga menjadi hambatan untuk memperluas dampak jaringan. Hal ini merupakan sebuah ancaman bagi Parani Car Wash, karena dapat menghambat perkembangan perusahaan. Penjelasan ini selaras dengan hasil wawancara dengan manajemen internal.

"Dampak selama ini, jaringan yang kami miliki masih belum cukup luas eh belum begitu luas ya, karena masih berkutak berkutak di sini aja, kita masih belum bisa berkembang ke area yang lebih besar" (J-4-FM-1).

"Dan untuk franchise kami udah mendapatkan penawaran dari Bangkalan, Solo, sing email wingi Kalimantan yo, empat limaan yo koyoke... Tapi karena kami belum ada badan hukum dan kami belum berani mengambil risiko ee untuk level yang tinggi” (M-4-AS-14).

Parani Car Wash yang merupakan perusahaan start-up memiliki gambaran yang kurang baik terhadap hubungan antara kegiatan yang dilakukan, sumber daya yang diperlukan, dan cara mengonfigurasi keterlibatan mitra dalam model bisnis serta dalam penciptaan value proposition (Lund dan Nielsen, 2014). Penelitian Lund dan Nielsen (2014) juga memberikan masukan kepada Parani Car Wash bahwa hubungan antara 
kegiatan yang dilakukan, sumber daya yang diperlukan, dan cara mengonfigurasi mitra dalam model bisnis adalah hal utama yang perlu diperhatikan.

\section{Pelanggan Perusahaan Cukup Puas}

Oliver pada Wu et al. (2016) mengartikan kepuasan pelanggan sebagai ringkasan keadaan psikologis yang dihasilkan ketika emosi yang mengelilingi harapan yang tidak cocok digabungkan dengan perasaan-perasaan yang terbentuk dalam pelanggan tentang pengalaman pengonsumsian, atau dengan kata lain tingkat kepuasan seseorang setelah membandingkan kinerja atau hasil yang dirasakan dibandingkan dengan harapannya. Berdasarkan hasil wawancara dengan pakar, hal yang perlu dipertimbangkan untuk memenuhi kepuasan pelanggan adalah mengetahui pain dan gain pelanggan.

"Hal yang dipertimbangkan untuk kepuasan pelanggan, ya kita harus tahu pain dan gain, titik. Ya itu hehehe" (I-4-GA-27).

Berdasarkan wawancara dengan internal perusahaan, dapat diketahui bahwa pelanggan Parani Car Wash puas dengan value proposition sistem panggilan dan pelayanan yang diberikan.

\footnotetext{
"Kalau kepuasan sih mereka merasa puas karena syukur ya aja ada cuci mobil panggilan gitu, ini gak perlu keluar rumah nih, kita cuma tunggu di rumah, terus kita udah tahu jadi, kayak gitu. Jadi mereka merasa terbantu" (L-6-AI-23).

"Beberapa juga ada yang puas sampai repeat order lagi, dan setiap Sabtu selalu mencuci” (M-4AS-19).
}

Pernyataan pelanggan berikut ini selaras dengan pernyataan internal perusahaan dan menunjukkan kepuasan selama menggunakan jasa Parani Car Wash.
"Udah sih, pelayanannya juga udah bagus, responsnya udah cepet, ee kalau mau order juga gampang. Cepet juga balesnya" (H-10-SD-30).

Namun pelanggan juga menunjukkan bahwa terkadang hasil cuci mobil kurang bersih, hal ini menunjukkan bahwa masih ada hal yang membuat pelanggan menyampaikan keluhan terhadap Parani Car Wash.

"Kurang interiornya. Terus, kaca depan itu kalau kita pakai itu masih ada noda itu di depan" (G-5EN-27).

"Iya sih aku pernah komplain kan, aku pernah nyuciin mobil si... eh siang, siang gitu sorenya komplain kan ini kok ada bekas-bekas air. Karena waktu itu jam operasionalnya udah habis kan, jam berapa waktu itu, terus besoknya aku iniin lagi, aku panggilin eh, aku minta komplain terus datang lagi untuk bersihkan kacanya itu" (H-6-SD-1).

Keluhan yang diterima perusahaan selalu direspons dengan tanggap oleh Parani Car Wash, hal ini selaras dengan hasil wawancara dari internal perusahaan.

"Ya tentunya kita terima kan. Kita minta maaf atas kesalahan kita, terus kita bilang kita nggak akan mengulangi atau kalo fatal ya kita kasih ganti rugi cuci mobil gratis, kayak gitu" (L-8- AI-7).

Parani Car Wash mampu memuaskan pelanggan dengan menyelesaikan permasalahan di mana pelanggan tidak perlu keluar rumah serta menyediakan air dan listrik, namun perusahaan masih menerima keluhan dalam hal teknis cuci. Melihat hal tersebut, dapat disimpulkan bahwa pelanggan Parani Car Wash cukup puas.

\section{Analisis Opportunity dan Threat}

1. Perusahaan dapat menghasilkan Pendapatan Berulang

Pendapatan berulang akan jauh lebih menguntungkan dibanding dengan pendapatan 
transaksional (Alt dan Zimmermann, 2014). Hasil wawancara dengan pakar menunjukkan cara perusahaan menghasilkan pendapatan berulang.

"Ya kalau mau mendapatkan repeat order ya tergantung dari yang pertama customer relationship dengan cutomer bagaimana, sistem kontrak kah, sistem subscription kan, sistem membership kah, sistem apa itu semua masuk kategori product model. Product modelnya seperti apa" (I-4GA-15).

Berdasarkan wawancara dengan pemilik usaha cuci mobil panggilan sejenis, meningkatkan kewaspadaan pelanggan bisa dilakukan melalui pesan singkat dan melakukan kerjasama dengan instansi untuk menghasilkan pendapatan yang berulang.

“... semuanya sih masih simple sih, jadi pakai sms, nomer pelanggan yang udah order kita simpen kita masukin ke group, maupun... pokoknya satu nama gitu, nah kita sms lagi gitu, setiap hari, kayak gitu." (E-7-EA-25)

“...Hast itu cucinya itu di misalkan, kayak di proyek pelabuhan Gresik, gitu, jadi nyuci nggak nyuci mobil, nyuci truk gitu, tapi lumayan, dua ratus lima puluh arma... apa... dua ratu lima puluh dump truk, terus misalkan nyuci di Toyota, itu kayak gitu-gitu... Instansi... iya" (E-4-EA-6).

"Agar pelanggan balik lagi gitu ya, ee saat ini kami mempunyai member card, nah kalau menurut kami itu salah satunya agar pelanggan bisa balik lagi, di mana member card itu terdapat ee informasi yang mencuci mobil ke-5 kali akan mendapatkan diskon 50\% seperti itu" (K-5-PW-17).

Hasil wawancara dengan internal perusahaan menunjukkan bahwa Parani Car Wash menggunakan diskon kartu anggota untuk menghasilkan pendapatan berulang.

"Agar pelanggan balik lagi gitu ya, ee saat ini kami mempunyai member card, nah kalau menurut kami itu salah satunya agar pelanggan bisa balik lagi, di mana member card itu terdapat ee infor- masi yang mencuci mobil ke-5 kali akan mendapatkan diskon 50\% seperti itu" (K-6- PW-23).

Bucklin dan Lattin dalam Yim dan Kwon (2015) membuktikan bahwa pembelian dilakukan melalui harga diskon menggunakan kupon akan memiliki dampak positif pada kemungkinan pembelian kembali. Seorang pelanggan yang diwawancarai juga menyatakan bahwa diskon tersebut cukup efektif untuk membuat pelanggan tertarik menggunakan jasa Parani Car Wash kembali.

"Adaaa, promo ini, dikasih stiker kan, eh kok stiker, stempel diskon $50 \%$ kalo udah 5 kali nyuci... Yaaa kan lumayan tuh kan kalo udah 6 kali diskon tuh, aku kan sering nyuci mobil tuh, nah kalau nyuci 6 kan lumayan dapet diskon, jadi cuci mobil untuk mengejar diskon hahaha" (H-9-SD-2).

Parani Car Wash memiliki kesempatan untuk lebih meningkatkan pendapatan berulang dengan cara meningkatkan kewaspadaan pelanggan melalui pesan singkat untuk membuat pelanggan tertarik untuk melakukan cuci kembali, dan Parani Car Wash juga dapat melakukan kerjasama dengan instansi baik pemerintah maupun swasta sehingga memiliki akses terhadap fasilitas. Hasil wawancara dengan internal perusahaan menunjukkan bahwa Parani Car Wash belum melakukan kerjasama dengan instansi.

"Pernah. tapi kami belum berani mengiyakan karena akses masuknya untuk ke tempat tersebut susah, perlu kerjasama, dan kami juga sedang mengusahakan proposal kerja sama tersebut" (M-4-AS-3).

"Ee ada yang memberi masukan kalau mereka ingin cuci mobil di wilayah apartemen, restoran, dan hotel... Nah untuk izin itu kami masih eee... kesulitan untuk mengurusnya" (K-5-PW-32).

2. Perusahaan Mampu Menentukan Kebutuhan Tambahan Pelanggan

Hasil wawancara dengan pakar menunjukkan cara menentukan kebutuhan tambahan pe- 
langgan adalah dengan menentukan minimum viable product.

\begin{abstract}
“...em vi pi, minimum viable product. Ya, ketika menentukan minimum product itu dia harus menentukan core, apa yang betul-betul core, kebutuhan inti, kemudian mana yang eee fitur, fitur tambahan, dan mana yang just nice" (I-5-GA-27).
\end{abstract}

Ries pada Keitcsh dan Roed (2014) menjelaskan bahwa minimum viable product (MVP) dapat digunakan untuk menguji dan mengurangi ketidakpastian apakah produk atau jasa akan memiliki pelanggan atau tidak. MVP juga harus selalu diperbarui secara terus menerus dengan pola Pelajari - Ciptakan - Ukur. Minimum Viable Product Parani Car Wash saat ini selain cuci mobil juga memberikan fitur gratis wax ban dan isi air sabun wiper kaca, hal ini mendapatkan respons yang baik dari pelanggan. Berdasarkan hasil wawancara dengan Pawestri, saat ini kebutuhan tambahan yang dibutuhkan oleh pelanggan berdasarkan tahapan Pelajari pada MVP Parani Car Wash adalah waxing. Sudah saatnya Parani Car Wash memulai tahap "Ciptakan” untuk memperbarui MVP.

“... pasti pelanggan itu ngomong, mbak nggak ada ini ya nggak ada ini tanya-tanya apakah ada kayak gini, misalkan pakai wax nggak mbak, di situ kan kita kelihatan kayak ooh berarti pelanggan tuh butuh ini looh butuh wax mungkin, pelanggan tu butuh yang kayak gini, karena sering tanya kan dari situ kita tahu” (L-4-AI-18).

\section{Perusahaan Mampu Menentukan Pelengkap atau Perluasan Proposisi Nilai}

Kaenzig et al (2013) dalam penelitiannya menunjukkan bahwa untuk memenuhi gap preferensi pelanggan, perusahaan dapat melakukan penentuan preferensi pelanggan dan mengetahui pentingnya atribut produk individual dalam pilihan konsumen. Pelengkap atau perluasan value proposition Parani Car Wash didasari pada preferensi pelanggan agar benar-benar mampu menjawab kebutuhan pelanggan. Berdasarkan hasil wawancara dengan pelanggan dan internal perusahaan, Parani Car Wash memiliki peluang untuk membuka armada baru dan menambah karyawan cuci menjadi dua orang untuk satu armada. Hal ini dapat mempercepat proses cuci, efisiensi biaya, memperluas wilayah operasional, dan dapat melayani cuci mobil pada lokasi yang berbeda di waktu yang bersamaan, sehingga dapat meningkatkan accessibility dan kepuasan pelanggan Parani Car Wash.

"Bisa, itu... itu sih, maksudnya nambah orang jadi satunya... Lima belas menit selesai gitu, enak kan hahaha jadinya cepet selesai” (H-8-SD-28).

"Menambah karyawan, dan ee membuka cabang jadi tidak hanya cakupan di Surabaya barat gitu. Nambah armada. Iya nambah armada, untuk efisiensi waktu kan juga berguna kan kalau misalnya menambah armada" (M-6-AS-33).

Berdasarkan hasil wawancara dengan perusahaan sejenis dan internal perusahaan, perusahaan cuci mobil harus memiliki berbagai varian cuci untuk melengkapi kebutuhan pelanggan. Parani Car Wash berencana untuk menambahkan varian cuci cepat, cuci premium, dan treatment detailing yang mencakup poles mobil, poles velg, jamur kaca, dan pembersihan jok mobil.

“...jadi ada itu, salon mobil, lha salon mobil itu di dalamnya ada yang bersihin joknya dari depan sampai belakang, lalu cuci mobil yang pake eksklusif, jadi harganya lebih mahal, peralatan sama bahan yang digunakan beda" (E-1-EA-20).

"Cuci cepat mungkin kita mengerjakan hanya eksteriornya, jadi hanya body. Kita tidak perlu waktu interior karena kita harus memotong waktu pekerjaan. Nah, kemudian ada treatment-treatment kaya menghilangkan jamur kaca. Kan sekarang banyak mobil-mobil yang konsumen apa orangorang tidak terlalu perhatian dengan kaca mobilnya" (J-10-FM-28). 
Parani Car Wash juga memiliki kesempatan untuk menggunakan teknologi cuci uap. Berdasarkan hasil wawancara dengan pemilik usaha cuci mobil konvensional, teknologi cuci uap memiliki banyak keuntungan, di antaranya adalah penggunaan air yang sedikit, pengerjaan lebih cepat karena tidak perlu proses menyabun, dapat membersihkan dan mensterilisasi interior tanpa merusak elektronik, dan menghilangkan noda di interior yang sulit dibersihkan. Penggunaan teknologi cuci uap pada Parani Car Wash dapat membuka peluang untuk mencuci mobil di tempat parkir yang tidak memiliki pembuangan air, seperti apartemen, hotel, perkantoran, dan lainlain. Berdasarkan hasil wawancara dengan pemilik usaha sejenis dan manajemen internal, penggunaan teknologi ini membutuhkan modal yang besar sehingga Parani Car Wash belum bisa diaplikasikan dalam waktu dekat mengingat keterbatasan modal yang dimiliki perusahaan, namun kedepannya perusahaan akan mempertimbangkan untuk bisa mengaplikasikan teknologi ini.

"Bukan, kalau uap kan ininya yang mahal, alate" (E-6-EA-32).

"Ya, jadi kita mungkin belum bisa menyamain value proposistion itu" (J-11-FM-21).

\section{Perusahaan Tidak Dapat Melakukan Pekerjaan Lain Demi Pelanggan}

Menurut Maine et al (2014) penciptaan peluang didefinisikan sebagai pengusaha yang membawa cara baru untuk menciptakan penerapan baru pada pasar. Jaakkola dan Hakanen (2013) menjelaskan bahwa pelanggan lebih mencari perusahaan yang dapat memberikan penawaran lebih terhadap solusi, hal ini mendorong sebuah perusahaan untuk mengembangkan solusi yang terintegrasi yaitu bundel produk atau jasa yang memenuhi kebutuhan spesifik pelang- gan, dan berpotensi menawarkan penciptaan nilai yang lebih besar daripada kebutuhan pelanggan. Berdasarkan hasil wawancara dengan pemilik usaha cuci mobil panggilan sejenis menjelaskan tentang kebutuhan tambahan pelanggan cuci mobil berkaitan dengan hal bersih-bersih lainnya, seperti contohnya membersihkan rumah.

“...kita cuci mobil yang bisa bersih-bersih misalkan, misalkan lah bersih-bersih rumah, atau gimana, lha kayak gitu" (E-8-EA-4).

Parani Car Wash belum bisa menentukan pekerjaan lain seperti yang dilakukan oleh Hast Car Wash, karena saat ini Parani Car Wash masih berfokus pada pengembangan jasa inti.

\section{Ketersediaan Jasa Pengganti}

Menurut Mathooko dan Ogutu (2015) ketersediaan barang atau jasa pengganti merupakan sebuah ancaman apabila menyediakan biaya yang lebih efektif dibandingkan produk dan jasa asli. Berdasarkan hasil wawancara dengan manajemen internal, ancaman bagi Parani Car Wash tidak hanya berasal dari cuci mobil panggilan, namun juga dari cuci mobil konvensional yang merupakan jasa substitusi.

"Jadi jasa pengganti kita kan tidak hanya cuci mobil panggilan, kan banyak yang stay kan yang di Surabaya barat. Jadi kita itu harus bersaing sama cuci mobil yang stay sama yang panggilan" (M-7-AS-27).

6. Pesaing Mengancam untuk Menawarkan Harga atau Nilai yang Lebih Baik

Menurut Dess dan Davis pada Kim (2015) pesaing adalah perusahaan yang memiliki ukuran, strategi, dan produk yang serupa, dan pesaing akan terus melakukan kompetisi untuk bisa memenangkan pasar. Selain sesama cuci mobil panggilan, cuci mobil konvensional yang juga merupakan kompetitor memiliki kelebihan sela- 
in dari harga yang lebih murah, waktu pengerjaan yang lebih cepat dan hasil cuci juga lebih bersih karena peralatan lebih lengkap dan dapat menjangkau bagian bawah mobil. Berdasarkan hasil wawancara dengan pelanggan, perusahaan cuci mobil konvensional ada yang memiliki hidrolis, sehingga mampu membersihkan bagian bawah mobil dengan lebih optimal jika dibandingkan tanpa hidrolis.

"Kan kalau kekurangannya model begini kan tidak pakai apa itu... (hidrolis)" (G-1-EN-19).

Hasil wawancara dengan pihak internal juga menunjukkan adanya ancaman dari kompetitor yang menawarkan harga yang lebih murah, kompetitor yang sudah menyediakan treatment detailing dan bisa mendatangi pelanggan, dan cuci tanpa air.

“...ada sih value cuci lain yang panggilan ada yang dia waterless, dia ga pakae air yang hanya disemprot. Nah, di situ kita belum bisa menyamai value seperti tersebut" (J-8-FM-34).

\section{Manfaat Indikator SWOT terhadap Value Pro- position}

Indikator SWOT dalam penelitian ini menghasilkan penilaian yang mampu memberikan masukan terhadap Parani Car Wash untuk menciptakan keunggulan kompetitif sehingga dapat bersaing di pasar. Hasil wawancara dengan pelanggan dan internal perusahaan memberikan gambaran mengenai kekuatan (strength) dan kelemahan (weakness) Parani Car Wash. Hal yang menjadi kekuatan Parani Car Wash adalah keselarasan value proposition dengan kebutuhan pelanggan dan pelanggan yang cukup puas, sedangkan yang menjadi kelemahan adalah Parani Car Wash tidak memiliki dampak jaringan yang luas. Sebelas value proposition yang pada awalnya berusaha dipenuhi oleh Parani Car Wash menimbulkan permasalahan. Oleh karena itu, Parani Car Wash perlu mengubah strateginya dengan hanya fokus pada beberapa value proposition sesuai dengan kekuatan dan peluang yang ada berdasarkan hasil analisis SWOT. Value proposition tersebut adalah Getting the Job Done, Convenience dan Performance. Dengan value proposition tersebut, Parani Car Wash masih bisa meningkatkan kinerjanya dengan melakukan perbaikan, seperti menambahkan varian cuci yang dapat memenuhi kebutuhan pelanggan dan menerapkan teknologi cuci yang lebih efisien. Parani Car Wash perlu segera mengambil peluang yang ada, yaitu menambah kerjasama dengan instansi untuk memperluas wilayah operasional dan menghasilkan pendapatan berulang.

\section{KESIMPULAN}

Hasil evaluasi value proposition dengan perspektif SWOT menunjukkan adanya kekuatan di mana value proposition perusahaan sudah selaras dengan kebutuhan konsumen dan pelanggan cukup puas dengan perusahaan. Namun masih ada kelemahan di mana Parani Car Wash tidak memiliki dampak terhadap jaringan bisnis. Selain itu, lingkungan eksternal membuka peluang berupa kerjasama dengan instansi untuk memperluas wilayah operasional dan memiliki peluang pendapatan berulang, menambah varian cuci dan treatment detailing sebagai pelengkap bagi perusahaan untuk menjawab kebutuhan pelanggan dan meningkatkan margin, penambahan armada dan karyawan untuk memperluas wilayah operasional dan efisiensi waktu, dan mengaplikasikan teknologi cuci uap untuk meningkatkan performa peralatan, efisiensi bahan bakar, air, dan waktu. Namun juga terdapat ancaman berupa banyaknya pesaing cuci mobil panggilan yang menawarkan harga lebih murah dan menyediakan value treatment detailing, dan 
jasa substitusi cuci mobil konvensional yang menawarkan harga yang lebih murah, peralatan cuci mobil yang lebih lengkap, dan tenaga kerja yang banyak sehingga mampu mencuci lebih cepat. Oleh karena itu, Parani Car Wash perlu fokus pada penawaran jasa inti, yaitu pada Value Proposition Getting the Job Done, Convenience dan Performance. Selanjutnya, Parani Car Wash disarankan untuk melakukan evaluasi secara berkala agar hasil perbaikan yang dilakukan lebih lengkap dan sesuai dengan kebutuhan dan keinginan pelanggan yang terbaharui. Parani Car Wash juga perlu melakukan komunikasi yang lebih intens untuk dengan konsumen untuk mengetahui kebutuhan, keinginan, kritik, san saran karena perusahaan tidak mengetahui penyebab konsumen yang tidak melakukan pembelian ulang.

Penelitian ini memiliki keterbatasan berkenaan dengan pengambilan data melalui wawancara semi terstruktur. Hal ini berpotensi menyebabkan masalah subjektivitas dari informan, sehingga dapat mengakibatkan hasil penelitian rentan terhadap biasnya jawaban informan. Untuk mengurangi bias, maka dilakukan triangulasi sumber dengan cara crosscheck dari berbagai data. Penelitian ini tidak dapat digeneralisasikan untuk perusahaan lain. Dan penelitian selanjutnya dapat diperluas dengan melakukan evaluasi value proposition pada usaha yang berbeda ataupun melakukan analisis SWOT terhadap elemen-elemen lain pada Business Model Canvas untuk mendapatkan hasil evaluasi yang lebih menyeluruh.

\section{DAFTAR RUJUKAN}

Alt, Rainer \& Zimmermann, Hanz-Dieter. 2014. Status of Business Model and Electronic Market Research: An Interview with Alexander Osterwalder. Electron Markets, 24, 243-249.
Bonazi, F.L.Z. \& Zilber, M.A. 2014. Innovation and Business Model: a case study about integration of Innovation Funnel and Business Model Canvas. Review of Business Management, 616-637.

Cassadeus-Masnell, R. \& Zhu, F. 2013. Business Model Innovation and Competitive Immitation: The Case of Sponsor-Based Business Model. Strategic Management Journal, 34(4), 464-482.

Dudin, M.K. et al. 2015. The Innovative Business Model Canvas in the System of Effective Budgeting. Asian Social Science, 11(7), 290-296.

Heinonen, Kristina. et al. 2013. Customer Dominant Value Formation in Service. European Business Review, 25 (2), 104-123.

Jaakkola, Elina \& Hakanen, Taru. 2013. Value Co-creation in Solution Networks. Industrial Marketing Management, 42, 47-58.

Kaenzig, Josef et al. 2013. Whatever the Customer Want, the Customer gets? Exploring the Gap between Consumer Preference and Default Electricity Products in Germany. Energy Policy, 53, 311-322.

Keitsch, M.M. \& Roed, J.B. 2014. Design Driven Innovation - Minimum Viable Products and Energy Solution in Rural Nepal. Proceeding of IOE Graduate Conference, 36-42.

Kerin, R.A. et al. 2013. Marketing. New York: McGraw-Hill Education.

Kim, Kwang-Ho. 2015. Competitor Identification through Vicarious Learning. Research Journal of Business Management, 9 (2), 303-318.

Lund, M. \& Nielsen, C. 2014. The Evolution of Network-based Business Models Illustrated Through the Case Study of an Entrepreneurship Project. Journal of Business Models, 105-121. 
Maine, Elicia. et al. 2015. The Role of Entrepreneurial Decision-making in Opportunity Creation and Recognition. Technovation, 1-20.

Mathooko, F.M \& Ogutu, Martin. 2015. Porter's Five Force Framework and other Factors that Influence the Competitive of Response Strategies adopted by Public Universities in Kenya. International Journal of Education Management 29 (3), 334354

Osterwalder, A. et al. 2014. Value Proposition Design. New Jersey: John Willey \& Sons, Inc.

Osterwalder, A. \& Pigneur, Y. 2010. Business Model Generation. Jakarta: PT Elex Media Komputindo.

Rangkuti, F. 2015. Analisis SWOT: Teknik Membedah Kasus Bisnis. Jakarta: PT Gramedia.

Setijawibawa, M. 2015. Evaluasi Model Bisnis pada Perusahaan X menggunakan Business Model Canvas. Agora, 3, 305-313.
Sugiyono. 2015. Metode Penelitian Manajemen. Bandung: Alfabeta.

Wu, Wen-Tsung. et al. 2016. Examining Paid Mobile Application Customer Loyalty: The Moderating Effect of Switching Costs. Business and Economic Research 6 (2), 100-117.

Yim, Ki-Heung \& Know, Jin-Hee. 2015. A Study on the Impact of Musical Reputation on Consumer Satisfaction and Wordof-Mouth Intention with On-linr Price Discount as a Moderating Variable. Indian Journal of Science and Technology 8 (8), 167-172.

Zacca, Robert \& Dayan, Mumin. 2015. Impact of Network Capability on Small Business Performance. Management Decision 53 (1), 2-23. 